\title{
USE OF REPELLENTS IN Cotesia flavipes (Cam.) (Hymenoptera: Braconidae) PUPAE FOR AERIAL RELEASE
}

\author{
VINHA, Fernando Belezini ${ }^{1}$ \\ RODRIGUES, Luis Rodolfo ${ }^{2}$ \\ PINTO, Alexandre De Sene ${ }^{3}$
}

\begin{abstract}
SUMMARY: The aerial release of Cotesia flavipes for the control of Diatraea saccharalis (F.) (Lepidoptera: Crambidae) in sugarcane is a reality that replaces the archaic and costly manual release, a strategy that will facilitate the biological control of the sugarcane borer. However, the pupal scattering of the parasitoid on the soil and plants could be compromised by predation. The use of repellents is a viable option and trichloroisocyanuric acid is effective in the repellency of predators in the field. Therefore, the objective of this work was to evaluate the effect of trichloroisocyanuric acid on the emergence and sexual ratio of $C$. flavipes in the laboratory and an evaluation of the repellency of predators in the field for this substance. In a completely randomized design, the following substances and amounts mixed with $C$. flavipes "masses" (set of pupae containing cocoons wrapped in silk threads) were tested: trichloroisocyanuric acid powder (55\%), liquid trichloroisocyanuric acid (3.3\%) plus odorless talc, trichloroisocyanuric acid (55\%) plus odorless talc and with only odorless talc (Control). Each treatment was repeated 15 times, each repetition being a "mass" placed in a flat bottom glass tube, closed with plastic film, all of which were kept in an air-conditioned room at $27 \pm 1^{\circ} \mathrm{C}$, RH of $70 \pm 10 \%$ and photophase of $14 \mathrm{H}$. The treatments were also repeated 20 times in the field. Each "mass" was placed in line at a distance of one meter, simulating an aerial release of 6,000 ha-1 parasitoids. After 12, 24 and $48 \mathrm{~h}$ of release, the masses were evaluated for predation. There were no significant differences between the treatments in the mean percentage of emergence and mean sexual ratio, which were respectively $61.25 \pm 8.11 \%$ and $0.74 \pm 0.06$. After $12 \mathrm{~h}$ of field release, the control treatment already had all the "masses" predated, whereas the treatment treated with trichloroisocyanuric acid powder did not show predation until $48 \mathrm{~h}$ after field release. These results indicate that trichloroisocyanuric acid, whether or not mixed with talc (for the individualization of "masses"), can be used with the parasitoid in $C$. flavipes aerial release equipment with a satisfactory effect on the repellency of predators.
\end{abstract}

Keywords: Release technique. Aerial release. Larval parasitoid.

\section{USO DE REPELENTES EM PUPAS DE Cotesia flavipes (Cam.) (Hymenoptera: Braconidae) PARA LIBERAÇÃO AÉREA}

RESUMO: A liberação aérea de Cotesia flavipes para o controle de Diatraea saccharalis (F.) (Lepidoptera: Crambidae) em cana-de-açúcar é uma realidade que vem substituir a arcaica e onerosa liberação manual, estratégia que facilitará o controle biológico da broca-da-cana. Entretanto, o espalhamento de pupas do parasitoide sobre o solo e plantas poderia ser comprometido pela predação. O uso de repelentes é uma opção viável e o ácido tricloroisocianúrico é eficaz na repelência de predadores no campo. Portanto, esse trabalho teve por objetivo avaliar o efeito do ácido tricloro-isocianúrico na emergência e razão sexual de $C$. flavipes, em laboratório e uma avaliação da capacidade de repelência de predadores em campo para essa substancia. Em um delineamento inteiramente casualizado, foram testadas as seguintes substâncias e quantidade misturadas às "massas" (conjunto de casulos contendo pupas, envoltos em fios de seda) de C. flavipes: pó de ácido tricloro-isocianúrico (55\%), solução líquida de ácido tricloro-isocianúrico $(3,3 \%)$ mais talco inodoro, ácido tricloro-isocianúrico $(55 \%)$ mais talco inodoro e com apenas talco inodoro (Controle). Cada tratamento foi repetido 15 vezes, sendo cada repetição uma "massa" colocada em um tubo de vidro de fundo chato, fechado com filme plástico, sendo todos mantidos em câmara climatizada a $27 \pm 1^{\circ} \mathrm{C}$, UR de $70 \pm 10 \%$ e fotofase de $14 \mathrm{~h}$. Os tratamentos também foram repetidos 20 vezes em campo. Cada "massa" foi colocada em linha a um metro de distância uma da outra, simulando uma liberação aérea de 6.000 parasitoides ha-1. Após 12, 24 e 48h da liberação, as massas foram avaliadas quanto à predação. Não houve

\footnotetext{
${ }^{1}$ Escola Superior de Agricultura "Luiz de Queiroz" - Graduado em Agronomia no CUML, Mestre em Entomologia pela ESALQ-USP, Pesquisador na Biocontrol. E-mail: fernandobevi@ hotmail.com

${ }^{2}$ Centro Universitário Moura Lacerda - Graduado em Agronomia, Pesquisador na Occasio.

${ }^{3}$ Centro Universitário Moura Lacerda - Graduado em Agronomia e Mestrado em Entomologia pela UNESP-FCAV, Doutorado em Entomologia pela ESALQ-USP, Prof. Dr. em Agronomia no CUML.
} 
diferenças significativas entre os tratamentos quanto à porcentagem média de emergência e razão sexual média, que ficaram, respectivamente, em $61,25 \pm 8,11 \%$ e $0,74 \pm 0,06$. Após 12 h da liberação em campo, o tratamento controle já tinha todas as "massas" predadas, enquanto o tratamento tratado com pó de ácido tricloro-isocianúrico não apresentou predação até 48 h após a liberação em campo. Esses resultados indicam que o ácido tricloro-isocianúrico, misturado ou não com talco (para a individualização das "massas"), pode ser utilizado junto ao parasitoide nos equipamentos de liberação aérea de $C$. flavipes com efeito satisfatório na repelência de predadores.

Palavras-chave: Técnica de liberação. Liberação aérea. Parasitoide larval.

\section{INTRODUCTION}

Brazil is the largest producer of sugarcane in the world. In the 2017/2018 harvest, it reached 8,73 million hectares planted and 633,26 million tons produced (average productivity of $77.7 \mathrm{t}$ ha-1) (CONAB, 2018). Sugar cane is an agroecosystem that shelters numerous species of insects, and some of them, depending on the time of year and region, can cause serious economic losses (PARRA; BOTELHO; PINTO, 2010). The most important among them is the sugarcane borer, Diatraea saccharalis (Fabr.) (Lepidoptera: Crambidae) (BOTELHO, MACEDO, 1988; PINTO, CANO; SANTOS, 2006). The control of this insect has been successfully carried out since the 1970s, using the larval and exotic parasitoid Cotesia flavipes (Cam.) (Hymenoptera: Braconidae), created massively in laboratories all over Brazil (PINTO, GARCIA, OLIVEIRA, 2006).

The release of $C$. flavipes is carried out costly, as the whole procedure is done manually. As the success of a biological control program may be hampered by the adopted release technique (PINTO; PARRA, 2002), some researchers have evaluated alternative ways to release parasitoids, reducing the need for labor. The main innovation was the spreading of these parasitoids directly on the culture (RAJENDRAN; MOHAMMED, 1998; MILLS et al., 2000; MARTINS, 2010), with the intention of performing this procedure with an airplane.

Predation is a serious problem when using release techniques where immobile biological forms (eggs or pupae) are not protected (OLIVEIRA et al., 2007). Thus, the pupal scattering of the parasitoid on the soil and plants by aerial application could be compromised by predation.

The use of repellents is a viable option in the repellency of predators in the field, preventing the C.flavipes pupae from being preyed before its emergence. The objective of this work was to evaluate the effect of trichloroisocyanuric acid on the emergence and sexual ratio of C.flavipes in the laboratory, besides evaluating trichloroisocyanuric acid in the field as a repellent of predators, especially ants, in the treatment of $C$. flavipes pupae for the simulation of an aerial release in cane fields.

\section{MATERIAL AND METHOD}

Laboratory experiments were conducted on the campus of the Moura Lacerda University Center in Ribeirão Preto, SP. For the field experiments a commercial area of sugarcane, with 4 months of development (2nd cut), var. IAC SP 93-3046, in Sertãozinho, SP, was used for the tests.

The "masses" (set of cocoons containing pupae grouped together with silk threads) from Cotesia flavipes were obtained from one of the commercial breeding laboratories of Biocontrol Biological Control System Ltda. -, in Sertãozinho, SP. The parasitoid was created on caterpillars of Diatraea saccharalis, its natural host, which in turn was raised on artificial diet, based on cane yeast and wheat germ. 


\section{LABORATORY TEST}

In a completely randomized design, the following substances and amounts mixed with $C$. flavipes "masses" (set of pupae containing cocoons wrapped in silk threads) were tested: (1) trichloroisocyanuric acid powder (55\%), (2) trichloroisocyanuric acid (55\%) plus odorless talc (3) liquid trichloroisocyanuric acid and (4) with only odorless talc (Control). Each treatment was repeated 15 times, each repetition being a mass placed individually in a flat bottom glass tube $(2 \mathrm{~cm}$ in diameter by $10 \mathrm{~cm}$ in height), identified and capped with plastic film, all being kept in a heated chamber at $27 \pm 1{ }^{\circ} \mathrm{C}, 70 \pm 10 \%$ $\mathrm{RH}$ and $14 \mathrm{~h}$ photophase. Using a stereoscopic microscope (10x magnification) and tweezers, after 5 days the contents of the tubes were removed and the number of emerged C. flavipes and the total number of cocoons were counted per "mass" to the determination of the emergency percentage $\left(\%\right.$ emergency $\left.=100 .\left(\frac{\text { no, emergad }}{\mathrm{mo}, \text { cocoons }}\right)\right)$ and sexual ratio $\left(\right.$ sexual ratio $=\frac{\text { na, females }}{\text { na, males }+ \text { na, females }}$. $)$.

\section{FIELD TEST}

For the field tests, the same "masses" treatment of $C$. flavipes from the laboratory experiment were performed, and these were repeated 20 times in the field and in a completely randomized design. Each "mass" was placed in line nine feet away from each other, glued on wooden sticks, simulating an aerial release of 6,000 ha-1 parasitoids. The assembly area of the experiment was two hectares and evaluated after 12, 24 and $48 \mathrm{~h}$ of release, the masses were evaluated for predation.

\section{STATISTICAL ANALYSIS}

All data were submitted to the homogeneity test of Levene variances at the 5\% level. The averages were calculated and submitted to a Tukey test at 5\% significance. All statistical calculations were performed by Statistica program for Windows (STATSOFT, 1996).

\section{RESULTS AND DISCUSSION}

After the treatment of C.flavipes masses in laboratory, it was possible to verify that all the products applied as repellents caused a slight reduction in the emergence rate of the pupae compared to the control treatment, one of the possible causes of these chlorine-based compounds are causing this toxicity is that they acts directly by contact and may be interfering with regulated sodium channels by changing the sodium and potassium balance, preventing nerve transmission normal, causing paralysis in the insect followed by death, a phenomenon known as "Knockdown", similar to the effect of the hexachlorocyclohexane insecticide (HOLAN, 1969; COATS, 1990).

Despite this, there were no significant differences between the treatments in the average percentage of emergence, which were respectively $61.25 \pm 8.11 \%$ (Figure 1 ). 
Figure 1. Average percentage of emergence of Cotesia flavipes pupae with the treatments (1) trichloroisocyanuric acid powder (Solid Chlorine), (2) trichloroisocyanuric acid plus odorless talc (Solid Chlorine + Talc), (3) liquid trichloroisocyanuric acid (Liquid Chlorine) and (4) with only odorless talc (Control). Columns ( \pm standard error of the mean) followed by the same letters has no significant difference by Tukey test $(\mathrm{p} \leq 0.05)$.

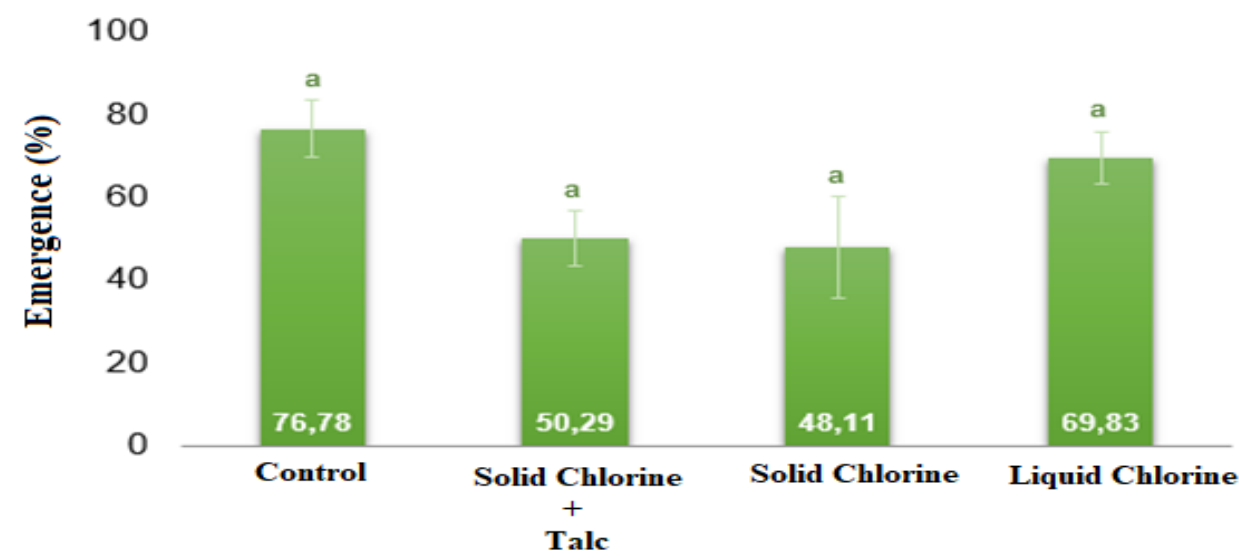

Source: Research Data.

For the sexual ratio test, the same result was obtained, and there were no significant differences in the treatments for the average sexual ratio, which were respectively $0.74 \pm 0.06$ (Figure 2). This result suggests that these chlorine-based compounds act exclusively by contact, because the cocoons of the surface of the mass were the most affected by the product, affecting both sexes.

Figure 2. Average sex ratio of Cotesia flavipes with the treatments (1) trichloroisocyanuric acid powder (Solid Chlorine), (2) trichloroisocyanuric acid plus odorless talc (Solid Chlorine + Talc), (3) liquid trichloroisocyanuric acid (Liquid Chlorine) and (4) with only odorless talc (Control). Columns ( \pm standard error of the mean) followed by the same letters has no significant difference by Tukey test $(\mathrm{p} \leq 0.05)$.

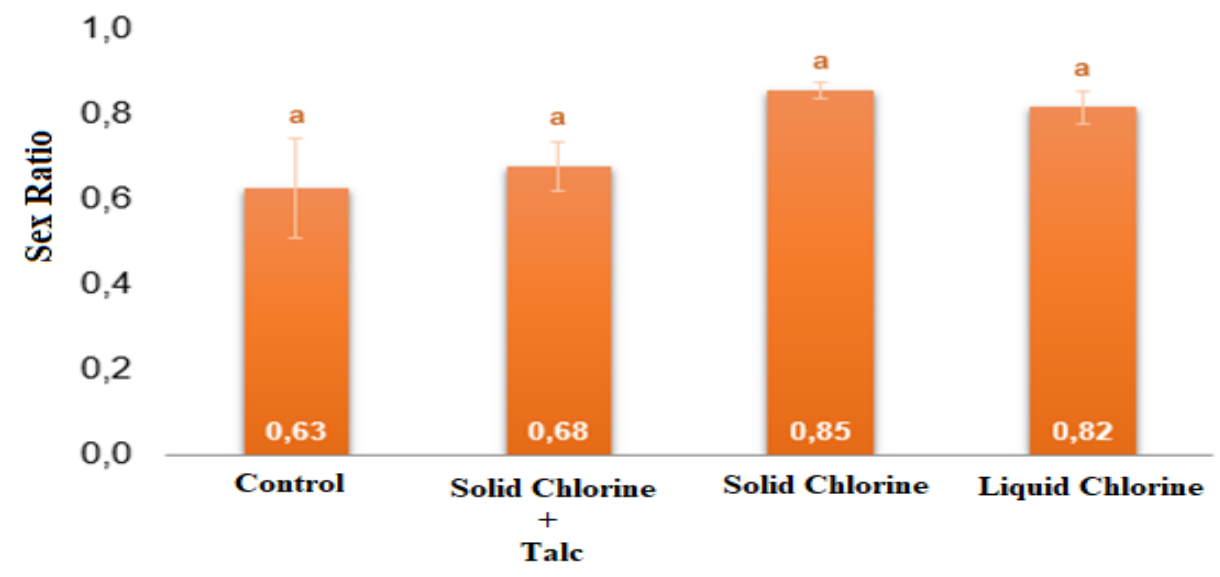

Source: Research Data.

In the field tests, after $12 \mathrm{~h}$ of the release, the treatment containing only odorless talc (Control) already had all the "masses" predated, not differing from the treatment treated with liquid trichloroisocyanuric acid plus talc (Figure 3). The treatment treated with solid trichloroisocyanuric acid did not show predation until $48 \mathrm{~h}$ after the release, being thus the treatment with greater effectiveness of repellency compared to the others. Predation of $C$. flavipes "masses" or fragments of them in all treatments were carried out mainly by ants. 
One of the explanations for the high number of ants in sugarcane is that the ants constitute one of the main groups of invertebrates in the soil (RISCH; JURGENSEN, 2008).Furthermore due to actions of environmental entities that originated the Law of the "Burning of the Cane" (Law no 11.241 / 2002), which deals with the substitution of manual harvest with burning by the mechanized, favored some insects in the crop, since the soil without the fires increased aeration and volume of organic matter (RISCH, JURGENSEN, 2008). In this way leaving the soil more structured, favoring the productivity of the system and the presence of generalist predators and parasitoids (SANDERS; VAN VEEN, 2011).

Figure 3. Predation of "masses " of Cotesia flavipes after 12, 24 and 48 hours with the treatments (1) trichloroisocyanuric acid powder (Solid Chlorine), (2) trichloroisocyanuric acid plus odorless talc (Solid Chlorine + Talc) , (3) liquid trichloroisocyanuric acid ( Liquid Chlorine) and (4) with only odorless talc (Control) in area of sugar cane. Solid Chlorine + talc. Geometric figures followed by the same letters has no significant difference by Tukey test $(\mathrm{p} \leq 0.05)$.

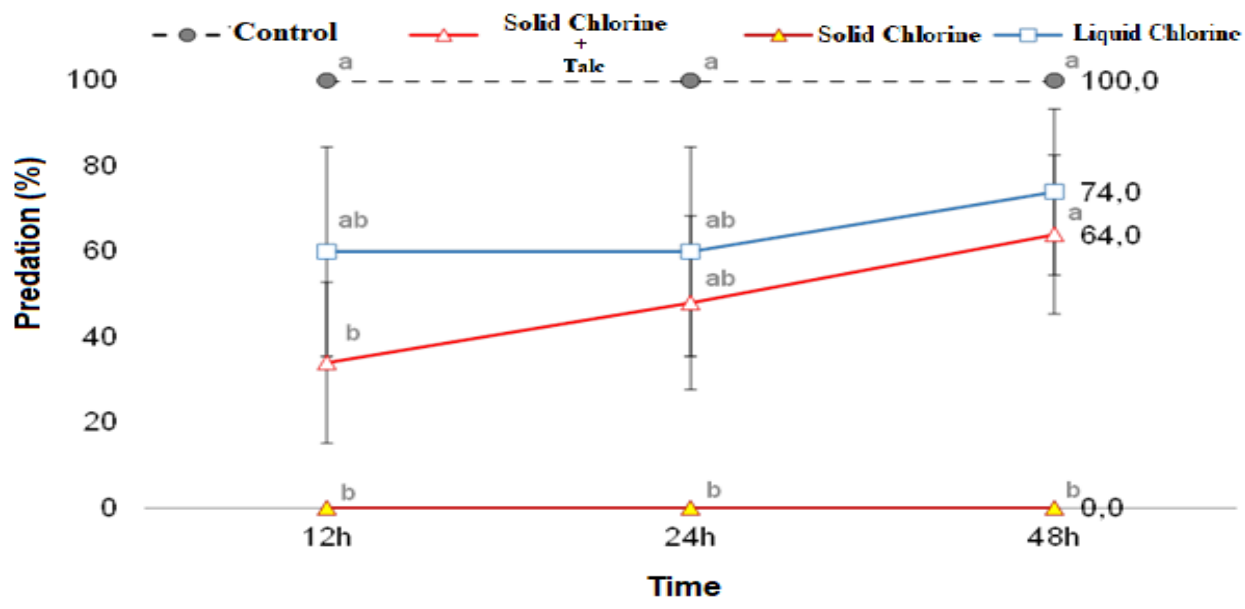

Source: Research Data.

\section{ACKNOWLEDGEMENTS}

The authors would like to thank José Edir Lovato for the area of sugarcane ceded to the experiments. This work was supported by the Biocontrol Biological Control System Ltda.

\section{CONCLUSION}

These results indicate that trichloroisocyanuric acid, mixed or not with talc (for the individualization of the "masses"), can be used as a predator repellent for $C$. flavipes.

\section{REFERENCES}

BOTELHO, P.S.M.; MACEDO, N. Controle integrado da broca-da-cana-de-açúcar Diatraea saccharalis (Fabr. 1974) (Lepidoptera: Pyralidae). Brasil Açucareiro, v.106, n.2, p.2-12, 1988.

COATS, J.R. Mechanisms of toxic action and structure- activity relationships for organochiorine and synthetic pyrethroid insecticides. Environ. Health. Perspect. v.87, p. 255-262, 1990. 
CONAB. COMPANHIA NACIONAL DE ABASTECIMENTO. Acompanhamento de safra brasileiro - cana-de-açucar: terceiro levantamento - safra 2018/2019. : Brasília: Companhia Nacional de Abastecimento. 2018. Disponível em: https://www.conab.gov.br/info-agro/safras/cana/boletim-da-safrade-cana-de-acucar. Acesso em: 01 jan. 2019.

HOLAN, G. New halocyclopropane insecticides and the mode of action of DDT. Nature n.221, p.10251029, 1969.

MARTINS, J.F. de O. Predação de pupas de Trichogramma pretiosum em diferentes técnicas de liberação e eficiência da técnica de espalhamento de pupas no controle de ovos de lepidópteros no campo. 2010. 37f. Monografia (Trabalho de Graduação em Agronomia) - Centro Universitário Moura Lacerda, Ribeirão Preto, 2010.

MILLS, N. et al. Mass releases of Trichogramma wasps can reduce damage from codling moth. California Agriculture, v.54, n.6, p.22-25, 2000.

OLIVEIRA, H.N. de et al. Predação de ovos parasitados por Trichogramma pretiosum em duas formas de liberação no campo. In: SIMPÓSIO DE CONTROLE BIOLÓGICO, 10, Brasília, 2007. [Anais...] Brasília: Embrapa Recursos Genéticos e Biotecnologia, 2007. (CD-ROM)

PARRA, J.R.P.; BOTELHO, P.S.M.; PINTO, A. de S. Controle biológico de pragas como um componente chave para a produção sustentável da cana-de-açúcar. In: CORTEZ, L.A.B. (Org.). Bioetanol de cana-de-açúcar: P\&D para produtividade e sustentabilidade. São Paulo: Blucher, 2010. p.441-450.

PINTO, A. de S.; CANO, M.A.V.; SANTOS, E.M. dos. A broca-da-cana, Diatraea saccharalis. In: PINTO, A. de S. (org.) Controle de pragas da cana-de-açúcar. Sertãozinho: Biocontrol, 2006. p.15-20. (Boletim Técnico Biocontrol, 1).

PINTO, A. de S.; GARCIA, J.F.; OLIVEIRA, H.N. de. Manejo das principais pragas da cana-de-açúcar. In: SEGATO, S.V.et al. (orgs.) Atualização em produção de cana-de-açúcar. Piracicaba: CP 2, 2006. p.257-280.

PINTO, A. de S.; PARRA, J.R.P. Liberação de inimigos naturais, cap.19. In: PARRA; J.R.P.et al. (orgs.). Controle biológico no Brasil: parasitóides e predadores. São Paulo: Manole, 2002. p.325-342.

SANDERS, D.; VAN VEEN, F.F. Ecosystem engineering and predation: the multitrophic impact of two ant species. Journal of Animal Ecology, v. 80, pp. 569-576, 2011.

RAJENDRAN, B.; MOHAMMED, H.A. Efficacy of different techniques for the release of Trichogramma chilonis Ishii, parasitising sugarcane internode borer, Chilo sacchariphagus (Kapur). Journal of Entomological Research, v.22, n.4, p.355-359, 1998.

RISCH, A.C.; JURGENSEN, M.F. Ants in the soil system - a hydrological, chemical and biological approach. Journal Applied of Entomology, v. 132, n. 4, p. 265, 2008.

STATSOFT. Statistica for Windows: computer program manual. Tulsa, OK: StatSoft Inc., 1996. 